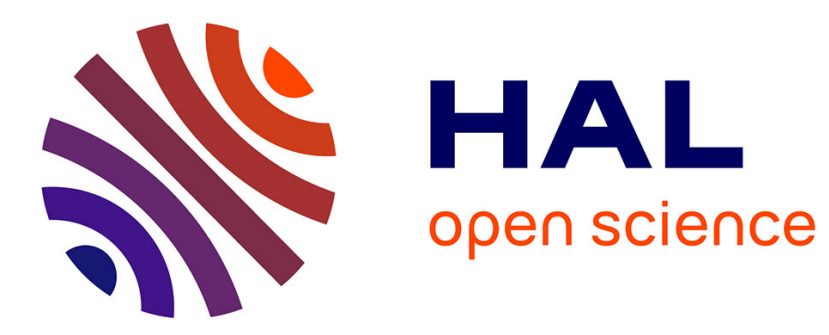

\title{
Variability of glyphosate and diuron sorption capacities of ditch beds determined using new indicator-based methods
}

Jeanne Dollinger, Cécile Dagès, Sandrine Negro, Jean-Stéphane Bailly, Marc Voltz

\section{To cite this version:}

Jeanne Dollinger, Cécile Dagès, Sandrine Negro, Jean-Stéphane Bailly, Marc Voltz. Variability of glyphosate and diuron sorption capacities of ditch beds determined using new indicator-based methods. Science of the Total Environment, 2016, 573, pp.716 - 726. 10.1016/j.scitotenv.2016.08.168 . hal01381031

\section{HAL Id: hal-01381031 \\ https://hal.science/hal-01381031}

Submitted on 15 Jun 2018

HAL is a multi-disciplinary open access archive for the deposit and dissemination of scientific research documents, whether they are published or not. The documents may come from teaching and research institutions in France or abroad, or from public or private research centers.
L'archive ouverte pluridisciplinaire HAL, est destinée au dépôt et à la diffusion de documents scientifiques de niveau recherche, publiés ou non, émanant des établissements d'enseignement et de recherche français ou étrangers, des laboratoires publics ou privés. 
Variability of glyphosate and diuron sorption capacities of ditch beds determined using new indicator-based methods

Jeanne Dollinger ${ }^{\mathrm{a}}$ *, Cécile Dagès ${ }^{\mathrm{a}}$, Sandrine Negro ${ }^{\mathrm{a}}$, Jean-Stéphane Bailly ${ }^{\mathrm{b}}$, Marc Voltz ${ }^{\mathrm{a}}$

a INRA, UMR LISAH, 2 Place Pierre Viala, 34060 Montpellier, France

${ }^{b}$ AgroParisTech, UMR LISAH, 2 Place Pierre Viala, 34060 Montpellier, France

E-mail address: jeanne.dollinger@supagro.inra.fr (J. Dollinger) 


\section{Introduction}

Farm ditch networks are engineered landscape features that are designed and managed to perform a variety of ecosystem services, including waterlogging control, soil erosion prevention, biodiversity conservation or water purification (Dollinger et al., 2015a; Herzon and Helenius, 2008; Levavasseur et al., 2016). The water purification potential of ditches has raised interests among institutions that are tasked with protecting water quality. Indeed, farm ditch networks play an important role in the fates of pesticides within cropped catchments.

Ditches collect drainage and runoff fluxes potentially loaded with pesticides and rout them downstream towards receiving water bodies or groundwater (e.g., Louchart et al., 2001). Despite constituting contaminants dispersal pathways because they link cropped fields with water bodies, ditches may have buffering effect for attenuating water pollution by pesticides according to their composition and hydraulic properties (Dollinger et al., 2015a; Herzon and Helenius, 2008; Needelman et al., 2007a). The high pesticide retention capacities reported for ditches have been attributed so far mainly to the sorption of pesticides to the various materials in the ditch beds although other biogeochemical processes e.g., biotic- and abiotic degradation or sedimentation of pesticides-loaded particles may, to some extent, also contribute to mitigate pesticides in ditches (Dollinger et al., 2015a; Stehle et al., 2011). Consequently, the buffering capacity of ditches is closely linked with the nature and profusion of the ditch-bed materials.

The main endogenous materials that provide efficient sorption sites for pesticides include soils and decaying and living vegetation. Ditch soils are formed from the accumulation of both field eroded particles and humified plant or algae residues and are structured due to root activity and drying/wetting cycles (Needelman et al., 2007b; Ruppert et al., 2014; Vaughan et al., 2008). Thus, the soil texture, structure and chemical composition in ditches are very site specific. Moreover, these nutrient-rich soils combined with particular hydrologic conditions provide ideal growth conditions for a variety of terrestrial and wetland plants (Herzon and Helenius, 2008; Needelman et al., 2007b). Consequently, ditches can be densely vegetated, and the natural decay of ditch plants and the input of dead leaves from surrounding trees and perennial crops (e.g., vineyards, orchards) may result in the formation of consequent litter layers (Levavasseur et al., 2014).

Managing farm ditches to maintain ecosystem services will modify the properties of the ditches, particularly the abundances of various bed materials in the ditches. Ditch management operations, i.e., dredging, chemical weeding, mowing and burning, impact the properties of ditches in contrasting ways (Dollinger et al., 2015a). Although dredging removes most materials from ditch beds, mowing and burning provide additional materials (e.g., hay and ash) that can have high sorption capacities (Dollinger et al., 2015a). Thus, farm ditch management can be used as an efficient method for protecting water quality in cropped catchments. Performing a diagnosis of farm ditch networks and designing appropriate management strategies requires good knowledge of the factors that drive pesticide adsorption and desorption in ditch beds.

The sorption capacities of ditch beds depend on 3 factors, the abundances and characteristics of the various bed materials, the relative affinity of a given pesticide for the available bed materials, and the hydraulic regime (Dollinger et al., 2015a). Adsorption and desorption coefficients measured in the laboratory using small samples are important but insufficient for characterizing the pesticide sorption capacities of ditch beds because they only provide information regarding the relative affinities of given pesticides to the various materials. Few studies have reported sorption coefficients for ditch soils, litter and wetland plants (e.g., Crum et al., 1999; Passeport et al., 2011; Rogers and Stringfellow, 2009; Vallée et al., 2014). Moreover, to our knowledge, the global sorption capacity of ditches resulting from their heterogeneous ditch-bed compositions has not been determined. Indeed, no methods are currently available for assessing the global sorption capacities of ditch beds with contrasting properties under varying hydraulic regimes based on operational, cost-effective and easily reproducible observations of ditch properties.

In this study, we therefore aimed at estimating the variations of the sorption capacities of ditch beds for glyphosate and diuron of catchments with different management, hydrological and pedological features. The specific objectives of this study were to i) identify the main drivers of the pesticide sorption capacity of ditch beds and ii) develop indicator-based methods suitable for analysing the ranking of sorption capacities of farmed ditches with contrasting properties and under varying hydraulic regimes. Three case studies are considered in the present study in three head-water catchments in France.

\section{Materials and methods}

\subsection{Physico-chemical properties of studied pesticides}

The herbicides glyphosate and diuron were selected for their potential contrasting sorption behaviours to ditch materials based on their physico-chemical properties (Table S1). Moreover, both herbicides are among the 15 pesticides that are most widely detected in surface water bodies and groundwater in France (SOeS, Ministère de l'Écologie, du Développement Durable et de l'énergie, 2013). Glyphosate [N-(phosphomethyl)glycine] is a zwitterionic molecule with strong hydrophilicity and very high water solubility (Table S1). The speciation of glyphosate varies with the $\mathrm{pH}$ of the surrounding environment (Dollinger et al., 2015b). Diuron (3-(3,4-dichlorophenyl)-1,1dimethylurea) is a hydrophobic molecule with moderate water solubility and remains neutral under environmental conditions (Table S1).

2.2. Sampling and measurement methods used to determine the properties of the ditch-bed materials

\subsubsection{Sampled ditches and ditch bed materials}

2.2.1.1. Selected ditches, soils and ash. Soils were sampled from ditch surface layers at different locations along ditch networks from 3 headwater catchments in different agricultural, climatic and pedological settings. Soils RO-D1-S through RO-D9-S (Table S2) were sampled from the Roujan catchment located south of France, which has a semi-arid Mediterranean climate and contains loamy soils and mainly vine crops (Andrieux et al., 1993). Soils RU-D1-S and RU-D2-S were sampled from the Ruiné catchment located west of France, which has an oceanic climate and contains clay soils and chalky soils on the plateaus and in the depressions (Vernier and Dubernet, 1997), respectively, and sunflower, corn, and vine crops. Soils M-D1-S and M-D2-S were sampled from the Morcille catchment located east of France, which is characterized by a continental temperate climate and contains sandy-loam soils and mainly vine crops (Rabiet et al., 2010). Ash samples were collected just after a burning event from the Roujan catchment. 
2.2.1.2. Living and dead vegetation. Dead vegetation, including dead leaves (RO-DL), hay (RO-Ha) and decaying plant residues (RO-DPR), was collected from ditches in the Roujan catchment. Plants, including Rubus fructicosus, Arum and Elytrigia, were collected from the Roujan catchment shortly before the experiments and were grown in the greenhouse before use to keep them fresh for the sorption experiments. The three perennial plant species collected in this study are wide spread and ubiquitous in the three sampled catchments. Rubus fructicosus is a ligneous species, and Elytrigia and Arum sp. are herbaceous and succulent species, respectively. Rubus fructicosus and Elytrigia colonize ditches all year, and Arum sp. is a winter species that grows between October and April. Farm ditches host a wide diversity of terrestrial and wetland plants (Herzon and Helenius, 2008). The plant species selected for this study provide an overview of the main types of vegetation that commonly colonizes farm ditches in France.

\subsubsection{Physico-chemical properties of the ditch-bed materials}

The particle size distributions, $\mathrm{pH}$ values, cation exchange capacities (CEC) and organic carbon, nitrogen and Olsen Phosphorus (P-Olsen) contents of the soil and ash samples were measured at the INRA-

ARRAS laboratory (France) using standardized methods as reported in Table S2. The soil bulk densities were estimated by sampling a known volume of soil and measuring the dry weight after oven drying for $24 \mathrm{~h}$ at $105{ }^{\circ} \mathrm{C}$.

The carbon, nitrogen, sulfur and residual ash contents of the decaying and living vegetation were measured at the INRA-USRAVE laboratory (France) using standardized methods as reported in Table S3. The bulk densities were evaluated using the water displacement method.

\subsubsection{Sorption properties of the ditch-bed materials}

2.2.3.1. Measurement of adsorption coefficients for ditch-beds materials. Soil and ash samples were air-dried to a target humidity of $10 \%$ (w-w) and passed through a $2 \mathrm{~mm}$ sieve. Leaves and stems from fresh plants were chopped into 3 to $5 \mathrm{~cm}$ fragments just before performing batch ex-

periments. Decaying vegetation samples were dried at $30{ }^{\circ} \mathrm{C}$ to a final humidity of $10 \%(\mathrm{w}-\mathrm{w})$. Shortly before the experiment, the dead leaves

were chopped into $3 \mathrm{~cm}$ fragments and mowing residues into 3 to $5 \mathrm{~cm}$ fragments. The dry weight and final humidity of all materials were determined from the difference of their mass before and after oven drying for $24 \mathrm{~h}$ at $105{ }^{\circ} \mathrm{C}$.

Sorption batch experiments were performed using ${ }^{14} \mathrm{C}$-labelled glyphosate and diuron (Isotop, Hungaria) with specific activities of 9.31 and $2.64 \mathrm{MBq} / \mathrm{mg}$, respectively. Solutions with glyphosate and diuron concentrations of 5,10,50,100 and $1000 \mu \mathrm{g} / \mathrm{l}$ were prepared in a $0.01 \mathrm{M} \mathrm{CaCl}_{2}$ and $200 \mathrm{mg} / \mathrm{NaN}_{3}$ electrolyte solution. Sodium azide was used to prevent microbial degradation during batch experiments. Because of the high specific activity of the labelled pesticides, the ${ }^{14} \mathrm{C}$ labelled solutions were mixed with non-labelled glyphosate and diuron (Sigma-Aldrich, France) solutions of equal concentrations. The labelled/ non-labelled solution ratios were $25-75 \%(\mathrm{v}-\mathrm{v})$ for glyphosate and 50$50 \%(\mathrm{v}-\mathrm{v})$ for diuron. A fixed volume of $10 \mathrm{ml}$ of each solution was added to the various materials, respectively, in glass centrifuge tubes with Teflon-lined caps. The solid-to-solution ratios $(\mathrm{g} / \mathrm{ml})$ for glyphosate were $1 / 10$ for soils, $1 / 5$ for decaying vegetation, $3 / 10$ for plants and $1 / 20$ for ash, and the solid-to-solution ratios for diuron were $1 / 5$ for soils, 1/10 for decaying vegetation, 1/10 for plants and 1/20 for ash. The solid-to-liquid ratios were chosen to be as close as possible to ditch conditions while respecting analytical constraints such as quantification limits. Slightly higher solid-to-liquid ratios were thereby chosen for materials with higher sorption potential. Batch experiments were conducted in triplicate. The centrifuge tubes were shaken for $24 \mathrm{~h}$ at supernatant solutions was performed in duplicate. Aliquots of $1 \mathrm{ml}$ were sampled from the supernatant solutions and mixed with $4 \mathrm{ml}$ of Ultima Gold scintillation liquid (PerkinElmer, USA) to measure activity using liquid scintillation counting (Tricarb2800, Perkin Elmer, USA). The amounts of pesticides in the materials were calculated from the difference in radioactivity between the initial and supernatant solutions. The pesticide concentrations in water at equilibrium were calculated from the activity data. The amounts of pesticide sorbed to each material were calculated using mass balance. Adsorption isotherms were represented by both linear (Eq. (1)) and Freundlich models (Eq. (2)).

$\mathrm{C}_{\mathrm{s}} 1 / 4 \mathrm{Kd} \mathrm{C}$

$\mathrm{C}_{\mathrm{s}} 1 / 4 \mathrm{Kf} \mathrm{C}_{\mathrm{w}}{ }^{\mathrm{n}}$

where $\mathrm{C}_{\mathrm{s}}$ is the amount of sorbed pesticides in the material at equilibrium $(\mu \mathrm{g} / \mathrm{kg}), \mathrm{C}_{\mathrm{w}}$ is the concentration in the supernatant $(\mu \mathrm{g} / \mathrm{l}), \mathrm{Kd}$ is the

linear sorption coefficient $(1 / \mathrm{kg})$, and $\mathrm{Kf}\left(\mu \mathrm{g}^{(1-n)} 1^{\mathrm{n}} \mathrm{kg}^{-1}\right)$ and $\mathrm{n}$ are the Freundlich coefficients.

2.2.3.2. Measurements of the desorption coefficients of the ditch-bed materials. Desorption batch tests were conducted for all materials in triplicate. After $24 \mathrm{~h}$ of equilibration with the solution at $100 \mu \mathrm{g} / \mathrm{l}$, the activity in the supernatant solution was measured as previously described (Section 2.2.3.1), and the residual supernatant solution was removed. Next, an equivalent volume of fresh electrolyte solution was added and the tubes were shaken again for $24 \mathrm{~h}$. Five successive desorption steps of $24 \mathrm{~h}$ each were performed. For each desorption step, the activity in the supernatant solution and the exact volumes of the removed supernatant and added electrolyte solutions were precisely measured. The amounts of pesticide sorbed to each material at each step were calculated using mass balance. Desorption isotherms were described using the Freundlich model (Eq. (2)). Hysteresis between corresponding adsorption and desorption isotherms was represented by the $\mathrm{H}$ parameter (Eq. (3)).

$\mathrm{H}^{1 / 4} \mathrm{n}_{\text {ads }}^{\underline{n_{\text {des }}}}$ љ3

$23 \pm 2{ }^{\circ} \mathrm{C}$ before centrifuging at $3000 \mathrm{rpm}$ for $10 \mathrm{~min}$. Preliminary kinetic batch tests showed that equilibrium was reached for all material/pesticide combination within b24 h. Radioactivity counting of the 
where $\mathrm{n}$ is the linearity parameter of the Freundlich isotherm (Eq. (2)) either for the adsorption isotherm $\left(\mathrm{n}_{\mathrm{ads}}\right)$ or for the desorption isotherm $\left(\mathrm{n}_{\mathrm{des}}\right)$.

2.2.3.3. Estimation of soil adsorption coefficients using pedotransfer functions. Pesticide adsorption coefficients are highly variable among soils because they depend on the soil physico-chemical properties (Dollinger et al., 2015b; Wauchope et al., 2002; Weber et al., 2004). Measuring adsorption coefficients can be expensive and time consuming, especially for soils, because ditch soils have a large range of sorption properties (Tables 1 and 2). Pedotransfer function for predicting soil and sediment adsorption coefficients are available for a wide range of molecules (Dollinger et al., 2015b; Moeys et al., 2011; Weber et al., 2004), including diuron. Here, we investigate the possibility of using these pedotransfer functions to estimate the diuron adsorption coefficients of ditch soils RO-D1-S to RO-D8-S, which were not experimentally measured. For diuron, the pedotransfer functions for estimating soil adsorption coefficients is based (Weber et al., 2004) on the organic matter content (Eq. (4)).

$\mathrm{Kd}_{\text {diuron }} 1 / 4$ 3:26 OM-0:1 $\mathrm{OM}^{2}-1: 4 \quad 1: 1 \mathrm{~cm}^{3}=\mathrm{g}$

where OM is the organic matter content (\%).

Accordingly, the Kd values of the ditch soil materials for diuron were estimated using Eq. (4) and the properties described in Table S2. Next, the set of experimentally measured Kd values (RO-D9-S, MO-D1-S, MO-D2-S, RU-D1-S and RU-D2-S) was compared with the predicted $\mathrm{Kd}$ values for these soils (data not shown), with a prediction accuracy 
Table

Diuron sorption coefficients of the ditch materials.

\begin{tabular}{|c|c|c|c|c|c|c|}
\hline Material & $\mathrm{Kd}_{\mathrm{ads}}$ & $\mathrm{R}^{2}$ & $\mathrm{Kf}_{\text {des }}$ & $\mathrm{n}_{\mathrm{des}}$ & $\mathrm{R}^{2}$ & $\mathrm{H}$ \\
\hline & $1 / \mathrm{kg}$ & & {$\left[\mu \mathrm{g}^{(1-\mathrm{n})} \mathrm{l}^{\mathrm{n}} \mathrm{kg}^{-1}\right]$} & & & \\
\hline RO-D1-S & $17.21^{\mathrm{a}}$ & nd & $114.66^{\mathrm{a}}$ & $0.32^{\mathrm{a}}$ & nd & nd \\
\hline RO-D2-S & $8.59^{\mathrm{a}}$ & nd & $114.66^{\mathrm{a}}$ & $0.32^{\mathrm{a}}$ & nd & nd \\
\hline RO-D3-S & $19.37^{\mathrm{a}}$ & nd & $114.66^{\mathrm{a}}$ & $0.32^{\mathrm{a}}$ & nd & nd \\
\hline RO-D4-S & $6.63^{\mathrm{a}}$ & nd & $114.66^{\mathrm{a}}$ & $0.32^{\mathrm{a}}$ & nd & nd \\
\hline RO-D5-S & $6.06^{\mathrm{a}}$ & nd & $114.66^{\mathrm{a}}$ & $0.32^{\mathrm{a}}$ & nd & nd \\
\hline RO-D6-S & $5.24^{\mathrm{a}}$ & nd & $114.66^{\mathrm{a}}$ & $0.32^{\mathrm{a}}$ & nd & nd \\
\hline RO-D7-S & $3.66^{\mathrm{a}}$ & nd & $114.66^{\mathrm{a}}$ & $0.32^{\mathrm{a}}$ & nd & nd \\
\hline RO-D8-S & $6.30^{\mathrm{a}}$ & nd & $114.66^{\mathrm{a}}$ & $0.32^{\mathrm{a}}$ & nd & nd \\
\hline RO-D9-S & 5.17 & 1.00 & 114.66 & 0.32 & 0.99 & 0.39 \\
\hline RU-D1-S & 2.91 & 1.00 & 86.41 & 0.27 & 0.99 & 0.34 \\
\hline RU-D2-S & 14.97 & 0.99 & 175.96 & 0.41 & 0.85 & 0.47 \\
\hline M-D1-S & 1.51 & 1.00 & 121.44 & 0.07 & 0.94 & 0.09 \\
\hline M-D2-S & 14.90 & 1.00 & 103.37 & 0.52 & 0.94 & 0.58 \\
\hline RO-DPR & 22.44 & 1.00 & 130.91 & 0.56 & 0.99 & 0.59 \\
\hline RO-DL & 46.53 & 1.00 & 140.79 & 0.70 & 0.96 & 0.60 \\
\hline RO-Ha & 28.62 & 1.00 & 40.28 & 0.97 & 0.99 & 0.99 \\
\hline RO-P1 & 2.58 & 0.98 & 181.81 & 0.17 & 0.63 & 0.18 \\
\hline RO-P2 & 2.15 & 1.00 & 30.70 & 0.71 & 0.97 & 1.06 \\
\hline RO-P3 & 3.15 & 0.98 & 222.32 & 0.15 & 0.85 & 0.18 \\
\hline RO-A & \multicolumn{2}{|c|}{100908} & 2196.98 & \multicolumn{2}{|c|}{0.00} & 0.80 \\
\hline
\end{tabular}

The desorption parameters $\mathrm{Kf}_{\mathrm{des}}$ and $\mathrm{n}_{\mathrm{des}}$ of soil RO-D9-S were used as proxies for the desorption parameters of soils from RO-D1, RO-D2, RO-D3, RO-D4, RO-D5, RO-D6, RO-D7 and RO-D8.

a The $\mathrm{K}_{\mathrm{ads}}$ values for soils RO-D1-S to RO-D8-S were estimated using the pedotransfer function (Section 2.3.2).

of $0.09 \mathrm{~cm}^{3} / \mathrm{g}$. Eq. (4) was very accurate, and the Kd values of RO-D1-S to RO-D8-S were then estimated using this pedotransfer function (Table 1).

2.3. Estimation of the pesticide sorption capacities of the ditch beds from in situ observations of ditch properties

2.3.1. Calculation of the adsorption coefficients for the composite ditch materials

Global adsorption coefficients for the composite ditch beds can be calculated from the relative masses of the individual materials and their respective sorption coefficients (Eq. (5), Appendix A). Eq. (5) is based on the following assumptions: i) the adsorption isotherms are linear and ii) the pesticide concentrations are uniform throughout the

Glyphosate sorption coefficients for the ditch materials.

\begin{tabular}{|c|c|c|c|c|c|c|}
\hline \multirow[t]{2}{*}{ Material } & $\mathrm{Kd}_{\mathrm{ads}}$ & \multirow[t]{2}{*}{$\mathrm{R}^{2}$} & $\mathrm{Kf}_{\mathrm{des}}$ & \multirow[t]{2}{*}{$\mathbf{n}_{\mathrm{des}}$} & \multirow[t]{2}{*}{$\mathrm{R}^{2}$} & \multirow[t]{2}{*}{$\mathrm{H}$} \\
\hline & $1 / \mathrm{kg}$ & & {$\left[\mu \mathrm{g}^{(1-\mathrm{n})} \mathrm{l}^{\mathrm{n}} \mathrm{kg}^{-1}\right]$} & & & \\
\hline RO-D1-S & 30.70 & 1.00 & 354.81 & 0.32 & 0.97 & 0.33 \\
\hline RO-D2-S & 26.15 & 1.00 & 410.11 & 0.20 & 0.94 & 0.22 \\
\hline RO-D3-S & 44.66 & 1.00 & 557.24 & 0.15 & 0.96 & 0.16 \\
\hline RO-D4-S & 23.58 & 0.99 & 388.34 & 0.22 & 0.98 & 0.23 \\
\hline RO-D5-S & 31.89 & 1.00 & 489.94 & 0.18 & 0.97 & 0.19 \\
\hline RO-D6-S & 64.86 & 1.00 & 508.03 & 0.21 & 0.94 & 0.22 \\
\hline RO-D7-S & 33.02 & 0.99 & 479.16 & 0.32 & 0.72 & 0.33 \\
\hline RO-D8-S & 69.15 & 0.99 & 448.19 & 0.17 & 0.99 & 0.17 \\
\hline RO-D9-S & 51.69 & 1.00 & 675.64 & 0.14 & 0.98 & 0.15 \\
\hline RU-D1-S & 302.63 & 1.00 & 1096.48 & 0.07 & 0.95 & 0.06 \\
\hline RU-D2-S & 262.41 & 1.00 & 1029.52 & 0.10 & 0.99 & 0.10 \\
\hline M-D1-S & 89.07 & 1.00 & 751.16 & 0.25 & 0.98 & 0.27 \\
\hline M-D2-S & 318.82 & 1.00 & 1067.30 & 0.04 & 0.79 & 0.04 \\
\hline RO-DPR & 5.25 & 1.00 & 56.84 & 0.44 & 1.00 & 0.49 \\
\hline
\end{tabular}

water column and in equilibrium with the sorbed pesticide concentrations on the ditch-bed materials.

$$
\begin{aligned}
& \mathrm{Kd}_{\text {ditch }} 1 / 4 \frac{M_{\mathrm{s}}}{M} \operatorname{Kdp} \frac{M_{\text {veg }}}{M} K_{\mathbb{R g}} \mathbf{p} \frac{M_{\text {DV }}}{M} \operatorname{Kdv} \mathbf{p} \frac{M_{\text {ash }}}{M} K_{\mathbf{d}}
\end{aligned}
$$

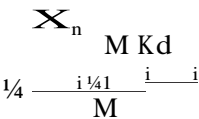

where $M_{s}, M_{v e g}, M_{D V}, M_{a s h}$ and $M$ are the masses of the soil, vegetation, decaying vegetation, ash, and the total composite material $(\mathrm{g})$, respec-

tively; $\mathrm{Kd}_{\mathrm{s}}, \mathrm{Kd}_{\mathrm{veg}}, \mathrm{Kd}_{\mathrm{DV}}$, and $\mathrm{Kd}_{\text {ash }}$ are the adsorption coefficients for

the soil, plants, decaying vegetation, and ash $\left(\mathrm{cm}^{3} / \mathrm{g}\right)$, respectively; $\mathrm{M}_{\mathrm{i}}$ is the mass of material $i$, where $i$ is one of the ditch materials [soil (s), decaying (DV) and living vegetation (veg) or ash (ash) (g)]; $\mathrm{Kd}_{\mathrm{i}}$ is the sorption coefficient of material $\mathrm{i}$; and $\mathrm{Kd}_{\text {ditch }}$ is the global sorption coefficient $\left(\mathrm{cm}^{3} / \mathrm{g}\right)$.

The masses of the different materials can be approximated from in situ observations of ditch properties (Section 2.3.3). It must be noted that the amounts of dead and living vegetation available for sorption vary among flood events with the water level. If the water level is lower than the total depth of the material layer, only a fraction of this layer is available for sorption. This effect may be significant, particularly for dead and living vegetation. For large ditches $(\approx 1 \mathrm{~m})$ with low water depths $(\mathrm{b} 15 \mathrm{~cm})$, the proportion of ditch-bank to ditch-bed materials is small. Consequently, ditch-bank materials are neglected when calculating $\mathrm{Kd}_{\text {ditch}}$.

2.3.2. Estimating the retention and remobilization of pesticides in the ditch beds

To assess the retention capacities of the ditch beds during a contaminated flood event, we propose computing an indicator that corresponds with the percentages of the pesticide flowing in the ditch that could potentially be retained by sorption on the bed materials. We refer to this indicator as SPRI (Sorption induced Pesticide Retention Indicator) hereafter. The SPRI is calculated based on the same hypothesis than that used for calculating the $\mathrm{Kd}_{\text {ditch }}$ (Section 2.3.1) but being based on a mass balance approach, it additionally supposes that the entire volume of water flowing in the ditch during a flood event is jointly in contact with all of the material surfaces below the water level and that sorption equilibrium with the different materials occurs nearly instantaneously. Thus, the estimated concentrations of the pesticides at the ditch outlet correspond with the concentrations in the water column when sorption equilibrium is reached with all of the materials in the ditch bed. The mathematical derivation of SPRI is described in

flowing in the ditch, the characteristics of the ditch and the sorption properties of the ditch-bed materials, as shown by the following equation:

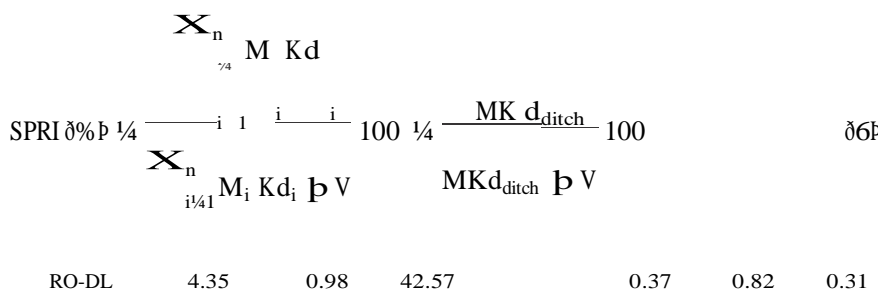


where $\mathrm{V}$ is the volume of water flowing in the ditch during a specific

time during a flood event $\left(\mathrm{cm}^{3}\right)$.

The contributions of each individual material to global pesticide re- tention during flood events with non-varying water levels and

\begin{tabular}{lllllll} 
RO-Ha & 0.77 & 0.98 & 4.30 & 0.67 & 0.75 & 0.68 \\
RO-P1 & 0.54 & 0.98 & 34.29 & -0.01 & 0.23 & -0.01 \\
RO-P2 & 0.30 & 0.97 & 26.98 & -0.13 & 0.63 & -0.17 \\
& & & & & & \\
RO-P3 & 2.04 & 0.97 & 59.27 & 0.01 & 0.52 & 0.01 \\
RO-A & 23.58 & 1.00 & 298.20 & 0.38 & 0.98 & 0.43 \\
\hline
\end{tabular}

constant initial aqueous concentrations was approximated by $\mathrm{FP}_{\mathrm{i}}$, which is the fraction of pesticides sorbed on material i relative to the total amount of sorbed pesticide (\%) (Eq. (7)).

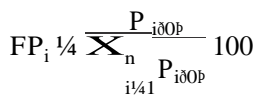

where $\mathrm{P}_{\mathrm{i}(\mathrm{O})}$ is the amount of pesticide sorbed on material $\mathrm{i}(\mathrm{g})$ and is computed by combining Eq. (1) and the mass balance equation as 
follows (see Appendix A, Eqs. (A-2) and (A-6)):

$$
\begin{aligned}
& \mathrm{C}_{\text {ini }} \\
& \mathrm{P}_{\mathrm{i} \tilde{\gamma} \mathrm{pp}} 1 / 4 \mathrm{C}_{\mathrm{w}} \mathrm{M}_{\mathrm{i}} \mathrm{Kd}_{\mathrm{i}}{ }^{1 / 4} 1 \mathbf{p ~ K d _ { \mathrm { i } }} \frac{\mathrm{M}_{\mathrm{i}}^{\mathrm{V}}}{\mathrm{M}_{\mathrm{i}} \mathrm{Kd}_{\mathrm{i}}}
\end{aligned}
$$

where $\mathrm{M}_{\mathrm{i}}$ is the mass of material $\mathrm{i}\left(\mathrm{i}=\mathrm{s}\right.$, veg, DV or ash), $\mathrm{C}_{\mathrm{w}}$ is the concentration in the water column at equilibrium $\left(\mathrm{g} / \mathrm{cm}^{3}\right)$ and $\mathrm{C}_{\mathrm{ini}}$ is the pesticide concentration in the inflow water $\left(\mathrm{g} / \mathrm{cm}^{3}\right)$.

The mass of pesticide that remains sorbed to each individual material after one flushing event with clear water $\left(\mathrm{P}_{\mathrm{i}(1)}\right)$ can be estimated from the Freundlich desorption model and mass balance by using a numerical solver (R Core Team, 2014). The fraction of the initially sorbed pesticides that is remobilized after one clear water flood event, $\mathrm{FD}_{\mathrm{i}}(\%)$, can be approximated as described in Eq. (9)

$$
\begin{aligned}
& \underline{\mathrm{P}}_{\mathrm{i} \tilde{\mathrm{i} \theta} \theta}-\mathrm{P}_{\mathrm{i} \tilde{\gamma} 1 \mathrm{p}} \\
& \mathrm{FD}_{\mathrm{i}}{ }^{1 / 4} \quad \mathrm{P}_{\mathrm{i} \gamma \mathrm{\gamma} 0 \mathrm{p}} \quad 100
\end{aligned}
$$

2.3.3. Approximating the amounts of ditch material from in situ observations

The qualitative operational method proposed by Bailly et al. (2015) for in situ observations of ditch properties was used to approximate the amounts of the different bed materials. Briefly, this method is based on precise measurements of ditch geometry (bottom and top width, depth and length) and visual estimates of vegetation, decaying vegetation, ash cover and the thicknesses of the material layers in a representative ditch segment of $5 \mathrm{~m}$. The masses of different materials can be derived from these observations using Eqs. (10) to (13). However, given the roughness of the vegetation and decaying vegetation layers, deriving the masses from in situ observations of the surface area covered by a given material and the maximum thickness of the layer requires good knowledge of the porosity of the layer. The porosities of plants, dead leaves and mowing residues were assessed by harvesting plants or decaying vegetation in 30 by $40 \mathrm{~cm}$ quadrats, where the layer depths were measured. The harvested plants and decaying vegetation were weighed in the laboratory, and the porosity was calculated as the ratio between the volume of the material (the dry mass of the material divided by its bulk density; see Table S3) to the volume of the layer.

$\mathrm{M}_{\mathrm{s}} 1 / 4 \mathrm{w}_{\text {bot }} \mathrm{L}_{\text {Ditch }} \rho_{\mathrm{s}} \mathrm{h}_{\mathrm{s}}$ ð10p

$M_{D V}^{1 / 4} w_{\text {bot }} L_{D i t c h} S_{D V} ð 1-p_{D V} p \min ð h_{D V} ; h_{w} p$

$$
\min \mathrm{h}_{\mathrm{veg}} ; \mathrm{h}_{\mathrm{w}}
$$

$\mathrm{M}_{\mathrm{veg}} 1 / 4 \mathrm{w}_{\text {bot }} \mathrm{L}_{\text {Ditch }} \mathrm{S}_{\mathrm{veg}} \quad 1-\mathrm{p}_{\mathrm{veg}}$

$\mathrm{M}_{\text {ash }} 1 / 4 \mathrm{w}_{\text {bot }} \mathrm{L}_{\text {Ditch }} \mathrm{S}_{\text {ash }} \rho_{\text {ash }} \mathrm{h}_{\text {ash }}$ where $\mathrm{w}_{\mathrm{bot}}$ is the bottom width of the ditch $(\mathrm{cm}), \mathrm{L}_{\mathrm{Ditch}}$ is the length of the ditch $(\mathrm{cm}), \rho_{\mathrm{i}}$ is the bulk density of the material $\mathrm{i}\left(\mathrm{g} / \mathrm{cm}^{3}\right), \mathrm{S}_{\mathrm{i}}$ is the fraction of the total surface area occupied by the material $i, h_{w}$ is the

water level $(\mathrm{cm}), \mathrm{p}_{\mathrm{veg}}$ is the vegetation porosity, $\mathrm{p}_{\mathrm{DV}}$ is the decaying vegetation porosity, and $h_{i}$ is the layer depth of material $i(\mathrm{~cm})$.

For the soil layer, a mixing zone with a depth of $2 \mathrm{~cm}$ is commonly assumed in modelling approaches (FOCUS, 2007). Thus the soil depth $\left(h_{s}\right)$ in Eq. (10) was set as $2 \mathrm{~cm}$. For the dead vegetation layer, the main type of decaying vegetation was considered in Eqs. (5) and (11).

\subsubsection{Case studies of ditch bed sorption capacity}

Eight ditches from the Roujan catchment were investigated on May 27th, 2013 (Table 3) to determine the properties of their beds using qualitative operational methods (Section 2.3.3). The masses from all materials were derived from these observations using Eqs. (10) to (13) and the porosity values reported in Tables S2 and S3. The charac-

teristics of the ditches are described in Table 3, and the properties of the bed soils are given in Table S2 (RO-D1-S to RO-D8-S).

We estimated the diuron and glyphosate adsorption capacities of ditch beds during contaminated flood events with varying concentrations and water levels by calculating the $\mathrm{Kd}_{\mathrm{dtich}}$ and SPRI values. The

contributions of the various bed materials to the global adsorption of ditch beds were also assessed. Finally, we estimated diuron and glyphosate desorption, the repartitioning of residual sorbed pesticides among various materials and the diuron and glyphosate concentrations in the water at the ditch outlets following a clear water flood event.

The global sorption coefficients for the 8 ditches $\left(\mathrm{Kd}_{\mathrm{ditch}}\right)$ were calculated using Eq. (5) for a normalized ditch length $\left(\mathrm{L}_{\text {Ditch }}\right)$ of $100 \mathrm{~m}$ and a normalized ditch width $\left(\mathrm{w}_{\text {bot }}\right.$ ) of $1 \mathrm{~m}$. These data were used to estimate the proportions of glyphosate and diuron that could be adsorbed in ditch beds during flood events with flowing volumes of 15, 30, 180, 429 and $749 \mathrm{~m}^{3}$ corresponding to water depths of $0.5,1,5,10$ and $15 \mathrm{~cm}$ (Eq. (6)). The proportions of pesticides retained in the ditch beds calculated using SPRI (Eq. (6)) did not vary with the pesticide concentrations in the water column because only linear adsorption isotherms were considered. However, the assessment of the contributions of each individual material to the total pesticide retention as well as the pesticide residues remaining after a clear water flushing event (Eqs. (7), (8) and (9)), depend on the aqueous pesticide concentrations. The repartitioning of adsorbed glyphosate and diuron among ditch materials was then calculated using Eqs. (7) and (8) for aqueous concentrations of 50 and $300 \mu \mathrm{g} / \mathrm{l}$, respectively, which are representative of the herbicide concentrations measured in the outlet ditch of the Roujan catchment (Dages et al., 2015). The masses of adsorbed glyphosate and diuron remaining in the ditch materials after 1 flushing step were calculated using Eq. (9), and their repartitioning among all

materials was calculated using Eq. (7) by replacing $\mathrm{P}_{\mathrm{i}(0)}$ with $\mathrm{P}_{\mathrm{i}(1)}$. The

\begin{tabular}{|c|c|c|c|c|c|c|c|}
\hline \multirow[t]{2}{*}{ Ditch ID } & \multirow{2}{*}{$\frac{\text { Vegetation cover }}{\%}$} & \multirow{2}{*}{$\frac{\text { Vegetation height }}{\mathrm{cm}}$} & \multirow{2}{*}{$\frac{\text { Litter cover }}{\%}$} & \multirow{2}{*}{$\frac{\text { Litter depth }}{\mathrm{cm}}$} & \multirow[t]{2}{*}{ Main decaying vegetation type } & \multirow{2}{*}{$\frac{\text { Ash cover }}{\%}$} & \multirow[t]{2}{*}{ Last visible management operation } \\
\hline & & & & & & & \\
\hline RO-D1 & 15 & N 15 & 60 & 5 & $\mathrm{Ha}$ & 0 & Not managed \\
\hline RO-D2 & 100 & N 15 & 0 & 0 & - & 0 & Not managed \\
\hline RO-D3 & 80 & N 15 & 15 & 1 & DL & 0 & Not managed \\
\hline RO-D4 & 18 & N 15 & 55 & 5 & $\mathrm{Ha}$ & 0 & Not managed \\
\hline RO-D5 & 30 & N 15 & 40 & 1 & $\mathrm{Ha}$ & 0 & Chemical weeding \\
\hline RO-D6 & 5 & N 15 & 15 & 1 & $\mathrm{Ha}$ & 50 & Chemical weeding \\
\hline RO-D7 & 1 & N 15 & 2 & 1 & $\mathrm{Ha}$ & 0 & Not managed \\
\hline RO-D8 & 10 & b 15 & 48 & 1 & $\mathrm{Ha}$ & 100 & Mowing \\
\hline RU-D1 & 50 & b 15 & 0 & 0 & - & 0 & Dredged \\
\hline RU-D2 & 10 & b 15 & 10 & 5 & $\mathrm{Ha}$ & 0 & Not managed \\
\hline
\end{tabular}
results are expressed as the proportions of the masses remaining in the different materials relative to the total mass initially adsorbed.

Table 3

Main properties of the ditches estimated from in situ observations. 
MO-D

0

MO-D2

0
b 15

0

0
1

$\mathrm{Ha}$

Ha: hay - DL: dead leaves. 
The unitary volumes flowing in the ditches during the flood events were approximated from the water depth to flowrate rating curve established for the outlet ditch of the Roujan catchment and correspond for all water depths to approximately $3 \mathrm{~h}$ floods depending on the vegetation density. This ditch is similar in shape to the RO-D1 and RO-D8 ditches.

Similar studies could not be performed for the other catchments due to missing information, namely the soil bulk densities. Nevertheless, the characteristics of the Ruiné and Morcille ditches are within the ranges of the characteristics of the 8 Roujan ditches (as shown in Table 3), which are sufficient for estimating the global variation of ditch sorption.

\section{Results and discussion}

\subsection{Ditch-bed material properties}

\subsubsection{Basic characteristics}

The ditch soils collected along the ditch networks of the Roujan, Ruiné and Morcille catchments have highly variable textures and chemical compositions (Table S2). Particularly, the organic carbon content varied by 1 to 7 fold among the soils collected from the ditches of a given catchment and was significantly higher than the organic carbon contents of the surrounding cropland (Dousset et al., 2010; Dages et al., 2015). This result is consistent with the site-specific pedogenic processes that were reported by Vaughan et al. (2008) and Needelman et al. (2007b), i.e., humification. The soil $\mathrm{pH}$ values are relatively constant across each network, with acidic soils in the Morcille catchment, neutral to basic soils in the Ruiné catchment and basic soils in the Roujan catchment (Table S2). The ditch soils contain high nutrient loads, especially nitrogen (Table S2), which may favour dense vegetation cover. The elementary ion compositions and $\mathrm{C} / \mathrm{N}$ ratios vary among plants species (Table S3), with Rubus fructicosus exhibiting the highest $\mathrm{C} / \mathrm{N}$ ratio. The variations in the $\mathrm{C} / \mathrm{N}$ ratios among species are inversely proportional to the residual ash content. The same trend was observed for decaying vegetation i.e., dead leaves and hay. This result suggests that the $\mathrm{C} / \mathrm{N}$ ratio is higher for living or dead vegetation that contains high concentrations of lignin, e.g., Rubus fructicosus or hay (Table S3).

The proportions of the various materials varied significantly among the 8 ditches investigated simultaneously in the Roujan catchment (Table 3). The nature and the proportions of the various ditch-bed materials were both related to pedological characteristics and management strategies (Dollinger et al., 2015a), which were different between the observed ditches. For example, litter layers were observed in ditches RO-D1, RO-D4, RO-D5, RO-D6 and RO-D8. Ditches RO-D5 and RO-D6 were chemically weeded the month before the survey and ditch RO-D8 was mowed. Ditches RO-D1 and RO-D4 were not managed in the month preceding the survey (Table 3) but earlier investigations (data not shown) indicate that these 2 ditches were chemically weeded and mowed, respectively, 2 months before the survey. Furthermore, denser vegetation cover was observed for ditches RO-D2 and RO-D3 (Fig. S1), which were not subjected to any management operations in the preceding month. The contrasting soil properties and the differing vegetation, decaying vegetation and ash profusion among the 8 ditches may result in composite ditch-bed materials with very contrasting sorptive properties.

\subsubsection{Sorption properties}

Both the linear and Freundlich models were satisfactorily adjusted to the experimental adsorption isotherms, and the Freundlich model was adjusted to the experimental desorption isotherms (Table S4, Tables 1 and 2). For both diuron and glyphosate, the adsorption coefficients $\left(\mathrm{Kd}_{\mathrm{ads}}\right.$ and $\left.\mathrm{Kf}_{\mathrm{ads}}\right)$ for the soils covered one order of magnitude. Moreover, the adsorption coefficients for the various soils were one to two orders of magnitude higher for glyphosate than for diuron, with $\mathrm{Kd}_{\mathrm{ads}}$ values ranging from 50 to $320 \mathrm{l} / \mathrm{kg}$ and 1.5 to $19 \mathrm{l} / \mathrm{kg}$, respectively.
Desorption hysteresis is commonly considered significant when $\mathrm{H}$ (Eq. (3)) is lower than 0.70 (Passeport et al., 2011). Accordingly, the desorption hysteresis was significant in all soils for diuron and especially glyphosate. The large variability in the adsorption and desorption behaviours among soils for both pesticides may be related to the different physico-chemical properties of the soils (Dollinger et al., 2015b; Wauchope et al., 2002; Weber et al., 2004).

Among all of the ditch-bed materials, the adsorption of diuron to ash was especially high and non-reversible. In addition, dead vegetation exhibited a strong sorption capacity for diuron, which did not vary much among the different types of decaying vegetation despite their different characteristics. Adsorption on living vegetation was relatively low and did not vary much from one plant species to another. However, desorption hysteresis is significant for Rubus fructicosus and Elytrigia but not for Arum sp. The adsorption of glyphosate on living and dead vegetation is 1 to 3 orders of magnitude lower than the adsorption of glyphosate on soils, and a significantly greater proportion of glyphosate was desorbed from living and dead vegetation than from soils (Table 2).

Among all of the ditch materials, the experimental sorption experiments show that diuron exhibits the greatest affinity for ash and dead vegetation, with less affinity for soils. This result corresponds with the studies of Garon-Boucher (2003) and Yang and Sheng (2003), who reported high diuron $\mathrm{Kd}_{\mathrm{ads}}$ values for dead leaves or humus and $\mathrm{Kd}_{\mathrm{ads}}$ values for crop burns that were approximately 1000 times higher than the $\mathrm{Kd}_{\text {ads }}$ values observed for soils. Moreover, among the ditch materials, glyphosate had the greatest affinities for soil and ash.

\subsection{Variability of the ditch bed sorption capacity}

\subsubsection{Global adsorption coefficients}

Composite ditch-material $\mathrm{Kd}\left(\mathrm{Kd}_{\text {ditch }}\right)$ values varied greatly among the ditches for both glyphosate and diuron with 2- and 9-fold variations, respectively, among the 8 ditches from the Roujan catchment (Table 4). The water level only slightly influenced the $\mathrm{Kd}_{\text {ditch }}$ values for both pesticides. However, a slight decreasing trend of $\mathrm{Kd}_{\mathrm{ditch}}$ was noticeable for all ditches when the water level increased, except for diuron in the ditches containing significant decaying vegetation layers (i.e., RO-D1, RO-D4 and RO-D5). For these ditches, the maximum $\mathrm{Kd}_{\text {ditch }}$ value was reached when the water level equalled the decaying vegetation depth. The values of $\mathrm{Kd}_{\mathrm{ditch}}$ were also greater for glyphosate than for diuron in the ditches containing ash and dense decaying vegetation layers. The values of $\mathrm{Kd}_{\text {ditch }}$ were very similar to those of the bed soils for glyphosate, which indicated that soils dominated the global sorption potential of the ditches for this substance. Given, the soil Kd values for glyphosate higher than the $\mathrm{Kd}$ values for the other ditch materials (Table 2) and, considering the very high apparent porosity of decaying and living vegetation (Table S3), the soils were from far the most abundant material in the ditch beds, with proportions of 85.6 to $99.9 \%$ of the total material masses in the 8 ditches. For diuron, the $\mathrm{Kd}_{\mathrm{ditch}}$ values were slightly greater than the soil Kd, particularly for ditches RO-D6 and ROD8, which were covered with thin layers of ash. Decaying vegetation did not influence the global diuron sorption capacity much because very little decaying vegetation was present relative to the amount of soil.

\subsubsection{Retention and remobilization during flood events}

The proportions of both glyphosate and diuron potentially retained by sorption during contaminated flood events and estimated by SPRI varied largely between the ditches (Table 5). The computed SPRI values for diuron were likely realistic because they were within the range of the diuron retention values observed by Margoum et al. (2003) for ditches with equivalent properties and water levels varying between 3 and $35 \mathrm{~cm}$. Margoum et al. (2003) measured diuron retention and observed that it varied from 3 to $39 \%$ in ditches characterized by different abundances of living and dead vegetation. The SPRI values significantly decreased when the water levels increased. Thus, the proportion of ditch-bed materials compared with the volume of the water column 
Table 4

Composite sorption coefficients $\left(\mathrm{Kd}_{\mathrm{ditch}}\right)$ of the ditch materials for glyphosate and diuron.

\begin{tabular}{|c|c|c|c|c|c|c|c|c|c|c|}
\hline \multirow[t]{2}{*}{ Ditch ID } & \multicolumn{5}{|c|}{$\mathrm{Kd}_{\text {ditch }}$ glyphosate } & \multicolumn{5}{|c|}{$\mathrm{Kd}_{\text {ditch }}$ diuron } \\
\hline & $0.5 \mathrm{~cm}$ & $1 \mathrm{~cm}$ & $5 \mathrm{~cm}$ & $10 \mathrm{~cm}$ & $15 \mathrm{~cm}$ & $0.5 \mathrm{~cm}$ & $1 \mathrm{~cm}$ & $5 \mathrm{~cm}$ & $10 \mathrm{~cm}$ & $15 \mathrm{~cm}$ \\
\hline RO-D1 & 30.60 & 30.49 & 29.70 & 29.50 & 29.30 & 21.97 & 21.97 & 22.01 & 21.86 & 21.71 \\
\hline RO-D2 & 26.01 & 25.87 & 24.82 & 23.62 & 22.53 & 9.40 & 9.35 & 8.95 & 8.50 & 8.09 \\
\hline RO-D3 & 44.49 & 44.31 & 43.07 & 41.61 & 40.25 & 26.00 & 25.91 & 25.17 & 24.30 & 23.48 \\
\hline RO-D4 & 23.50 & 23.42 & 22.80 & 22.59 & 22.40 & 7.16 & 7.22 & 7.64 & 7.57 & 7.50 \\
\hline RO-D5 & 31.79 & 31.68 & 31.33 & 30.90 & 30.48 & 6.48 & 6.52 & 6.44 & 6.35 & 6.26 \\
\hline RO-D6 & 64.19 & 64.13 & 64.01 & 63.86 & 63.72 & 20.40 & 20.40 & 20.36 & 20.31 & 20.27 \\
\hline RO-D7 & 33.02 & 33.01 & 33.00 & 32.99 & 32.98 & 3.79 & 3.79 & 3.79 & 3.79 & 3.79 \\
\hline RO-D8 & 67.65 & 67.48 & 67.24 & 66.94 & 66.64 & 35.75 & 35.72 & 35.59 & 35.43 & 35.27 \\
\hline
\end{tabular}

also decreased, leading to less favourable conditions for adsorption processes. Indeed, when the water level increased from 0.5 to $15 \mathrm{~cm}$, a general SPRI decrease of approximately $90 \%$ was recorded in all ditches (Table 5). Again this result is consistent with the findings of Margoum et al. (2003), who detected the significant retention of diuron only when the water depths were lower than $10 \mathrm{~cm}$ for ditches $100 \mathrm{~m}$ long.

The repartitioning of adsorbed glyphosate and diuron among the various bed materials (Fig. 1) shows that soils are the main adsorbents, which was expected from the analysis of the $\mathrm{Kd}_{\text {ditch }}$ values. Soils accounted for nearly all of the glyphosate adsorption, with only a small fraction of glyphosate adsorbed by ash. The fractions of diuron adsorbed by plants and decaying plants are very low and low, respectively, compared with the fraction of diuron adsorbed by soils, although the $\mathrm{Kd}_{\mathrm{DV}}$ value is much larger than the $\mathrm{Kd}_{\text {soil }}$ values. However, despite the very low mass of ash compared with the mass of the soil in ditches RO-D6 and RO-D8, the ash accounted for 73 and $81 \%$ of the total diuron adsorption (Fig. 1). Indeed, diuron exhibits a very high affinity for ash (Table 1). Accordingly, the repartitioning of adsorbed glyphosate and diuron among the various ditch materials did not vary much with water level fluctuations (Fig. 1). In fact, even at the lowest water level, all of the soil and ash were assumed to be in contact with the water column. However, the roles of soils in the sorption capacities of ditches may be more important for glyphosate and diuron than for more hydrophobic pesticides that have previously exhibited affinities for living and dead vegetation that were from 1 to 3 orders of magnitude higher than their affinities for soil (Dollinger et al., 2015a).

The estimated fraction of desorbed pesticides after clear water flood events depends on the initial contamination, desorption behaviours of the pesticides from various materials and water level of the clear water flood events (Fig. 2). For ditches from the Roujan catchment, the estimated fraction of pesticides desorbed after clear water flood events varied from $0.04 \%$ to $94.6 \%$ for glyphosate and from $2.8 \%$ to 95.3\% for diuron, with the greatest desorption rates estimated for high initial pesticide loads and high water levels for both contaminated and non-contaminated flood events (Fig. 2). Due to the non-linearity of the desorption isotherms, the percentages of pesticide desorbed from the ditch beds varied with the initial amount of pesticide adsorption. The estimated fraction of pesticides desorbed was greater for high amounts of initially adsorbed pesticide than for lower amounts of initially adsorbed pesticide. Moreover, the proportion of desorbed pesticides during high water level flows was larger because the solidto-liquid ratio decreased when the water level increased. Moreover, the desorption intensity varied between the bed materials. After a clear water flood event, the glyphosate and diuron initially adsorbed on decaying vegetation and plants and the glyphosate initially absorbed on ash were nearly completely desorbed. In fact, the relatively low abundances of these materials result in very low solid-to-liquid ratios and, consequently, conditions that are favourable for desorption processes. In contrast, the outstanding desorption hysteresis from ash counterbalances the effects of a very low solid-to-liquid ratio for diuron. Among all of the ditch materials, soils exhibited the lowest desorption potential (Fig. 2) for glyphosate. The same trend was observed for diuron in ditches RO-D1, RO-D2, RO-D3, RO-D4, RO-D5 and RO-D7. However, the exceptionally low desorption rates in the ditches covered by thin layers of ash that resulted from burning operations were attributed to the ash. Accordingly, the sorption capacity ranking differed slightly after a clear water flood event when compared with after an initial contaminated event, particularly for ditches containing ash.

The estimated glyphosate and diuron concentrations at the ditch outlets after their remobilization from the ditch beds due to a flushing event varied greatly among the ditches and with the characteristics of both initial and flushing floods (Fig. 3). However, even for ditches with high estimated desorption rates, the glyphosate and diuron concentrations at the ditch outlets after a flushing event were b $50 \%$ of the initial concentrations in the ditches (Fig. 3). Thus, even if the long term pesticide retention capacity of ditch beds is limited due to reversible adsorption processes, ditches can be expected to buffer pesticide concentrations in receiving water bodies and thereby reduce the risks of acute toxicity in these ecosystems (e.g., Bundschuh et al., 2016; Werner et al., 2010).

\subsection{Estimation of ditch beds sorption capacity: potential and limitations}

Estimating the global pesticide sorption capacity of ditch beds using $\mathrm{Kd}_{\text {ditch }}$, SPRI and the following potential of desorption (Eq. (9)) based on simple in situ observations of ditch properties enables for rapid and cost-effective ranking of ditches regarding their potential of water purification and the a priori identification of the effects of different management strategies on the retention of pesticides in ditch beds. $\mathrm{Kd}_{\mathrm{ditch}}$ and SPRI provided equivalent ranking for the investigated ditches regarding

Table 5

Sorption induced pesticide retention indicator (SPRI).

\begin{tabular}{|c|c|c|c|c|c|c|c|c|c|c|}
\hline \multirow[t]{2}{*}{ Ditch ID } & \multicolumn{5}{|c|}{ SPRI glyphosate (\%) } & \multicolumn{5}{|c|}{ SPRI diuron $(\%)$} \\
\hline & $0.5 \mathrm{~cm}$ & $1 \mathrm{~cm}$ & $5 \mathrm{~cm}$ & $10 \mathrm{~cm}$ & $15 \mathrm{~cm}$ & $0.5 \mathrm{~cm}$ & $1 \mathrm{~cm}$ & $5 \mathrm{~cm}$ & $10 \mathrm{~cm}$ & $15 \mathrm{~cm}$ \\
\hline RO-D1 & 84.76 & 73.09 & 31.44 & 16.10 & 9.91 & 79.97 & 66.18 & 25.37 & 12.45 & 7.53 \\
\hline RO-D2 & 80.12 & 66.32 & 24.97 & 12.24 & 7.41 & 59.29 & 41.56 & 10.71 & 4.78 & 2.80 \\
\hline RO-D3 & 89.21 & 80.16 & 40.55 & 22.21 & 14.07 & 82.86 & 70.26 & 28.50 & 14.29 & 8.72 \\
\hline RO-D4 & 79.94 & 66.06 & 24.74 & 12.09 & 7.31 & 54.85 & 37.50 & 9.92 & 4.04 & 2.57 \\
\hline RO-D5 & 84.96 & 73.39 & 31.77 & 16.30 & 10.05 & 53.53 & 36.20 & 8.74 & 3.85 & 2.24 \\
\hline RO-D6 & 92.14 & 85.13 & 49.14 & 28.78 & 18.80 & 78.84 & 64.56 & 23.51 & 11.39 & 6.86 \\
\hline RO-D7 & 88.29 & 78.65 & 38.33 & 20.63 & 12.97 & 46.42 & 29.74 & 6.67 & 2.90 & 1.68 \\
\hline RO-D8 & 92.68 & 86.07 & 51.05 & 30.37 & 20.00 & 86.99 & 76.59 & 35.57 & 18.76 & 11.68 \\
\hline
\end{tabular}



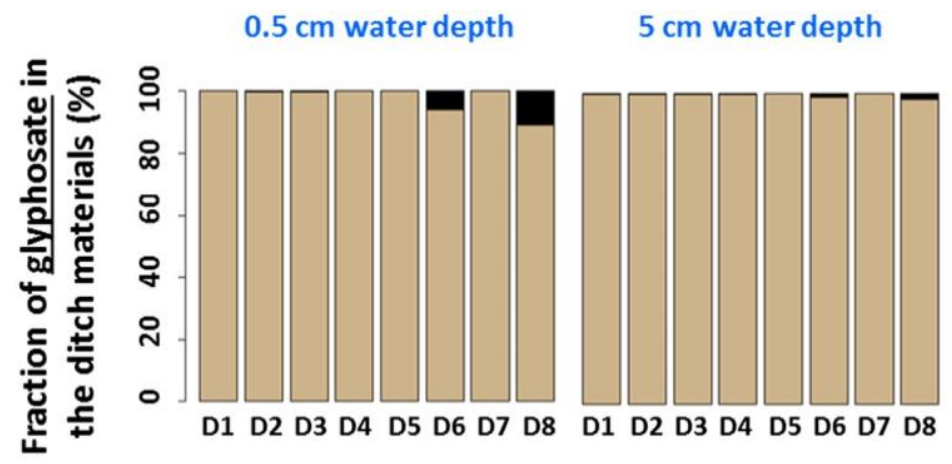

$15 \mathrm{~cm}$ water depth

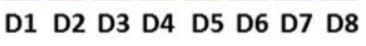

$\begin{array}{llllllll}\text { D1 } & \text { D2 } & \text { D3 } & \text { D4 } & \text { D5 } & \text { D6 } & \text { D7 } & \text { D8 }\end{array}$

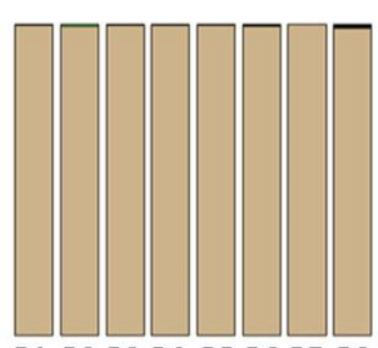

D1 D2 D3 D4 D5 D6 D7 D8
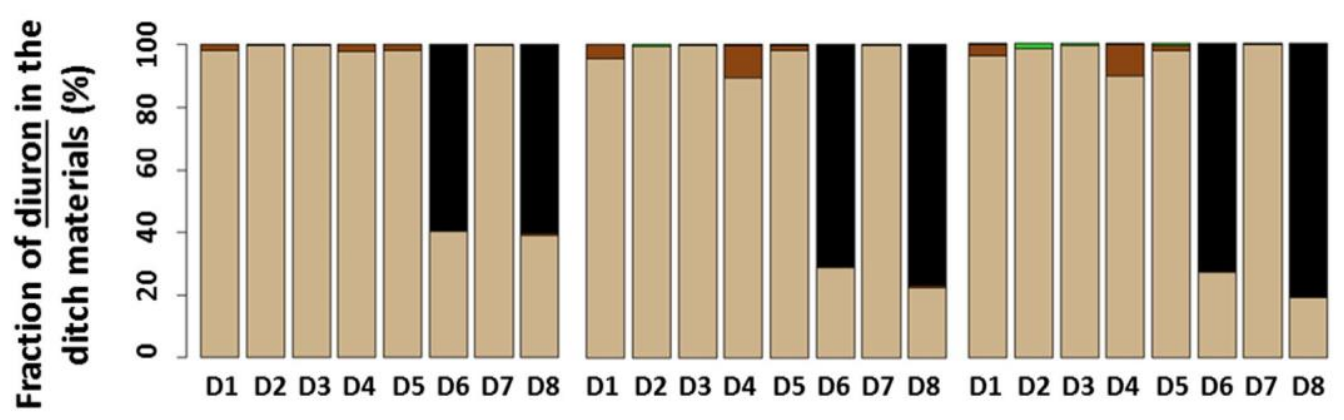

\section{$M_{\text {pesticide-soil } \square} M_{\text {pesticide-litter }}$}

$\mathbf{M}_{\text {pesticide-plants }}$

$M_{\text {pesticide-ash }}$

Fig. 1. Distribution of the relative mass of adsorbed glyphosate and diuron among the various ditch materials. Distribution of adsorbed glyphosate and diuron in the soil, litter, vegetation

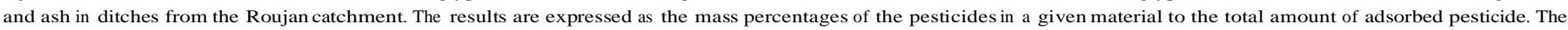
distribution was calculated for water levels of $0.5,5$ and $15 \mathrm{~cm}$ and is not dependent on the initial concentration as only linear sorption isotherms are considered.

their pesticide adsorption capacities because they are based on the same hypotheses. However, because $\mathrm{Kd}_{\mathrm{ditch}}$ ranks ditches only on basis of the affinities of the pesticide to the ditch-bed materials and their relative abundance, SPRI allows for a more quantitative assessment of pesticide retention because it is based on a mass balance approach. The SPRI values estimated for the 8 ditches from the Roujan catchment (Table 5) are in the range of the measured pesticide retention capacities reported for ditches according to the review of Dollinger et al. (2015a) (between 3 and 99\%).

This approach, however, has several limitations due to the accuracy of the input data (e.g., the relative amounts of the different materials) and due to some hypotheses underlying the calculations of $\mathrm{Kd}_{\mathrm{ditch}}$ and SPRI.

The in situ characterization of ditch properties in a network is difficult because of the spatially very heterogeneous conditions of ditches. The visual inspection of ditch properties (Bailly et al., 2015) can provide estimates of the respective amounts of various ditch-bed materials. However, estimates of the porosities of living and dead vegetation layers are approximate because they vary with the type of vegetation and change when the vegetation decays or when compaction occurs due to successive flood events. However, given the low contribution of both materials in ditch ranking towards their sorption capacities of diuron and glyphosate, a light bias in the porosity assessments would have little influence on the final ditch rankings.

For computing $\mathrm{Kd}_{\text {ditch }}$ and SPRI, it was assumed that all flowing water is mixed simultaneous and perfectly with the adsorbing ditchbed materials and that equilibrium is instantaneous. This assumption differs from the actual conditions in ditches, where water flows rather quickly and possibly heterogeneously. The difference between this assumption and reality may lead to several estimation biases that may compensate for each other. The actual water flow in ditches may indeed be fast and concentrated into specific pathways then limiting the contact time and the fraction of adsorbing material in contact with the diluted pesticide and in turn, limiting the pesticide sorption compared with the hypothesis of a simultaneous contact of the solution with all ditch bed materials. In contrast, the assumption that perfect mixing and instantaneous equilibrium occurs tends to overestimate the adsorption capacity. The observed equilibrium times of diuron and glyphosate with the various ditch-bed materials ranged from $5 \mathrm{~min}$ to $3 \mathrm{~h}$ but didn't vary much for a given material type e.g., soil, litter, vegetation (data not shown). Thereby, even if the absolute value of SPRI may be affected by non-equilibrium sorption, the ranking between ditches would not be affected.

Finally, to simplify the calculations, the ditch bank materials were neglected when calculating $\mathrm{Kd}_{\text {ditch }}$ and SPRI. However, for ditches with a width of $1 \mathrm{~m}$ and water depths of 10 to $20 \mathrm{~cm}$, the proportion of ditch-banks compared with the ditch-bed materials becomes significant, potentially representing up to $50 \%$ of the bed material mass for a water depth of $20 \mathrm{~cm}$. Neglecting the ditch bank materials when calculating $\mathrm{Kd}_{\mathrm{ditch}}$ and SPRI would then lead to great underestimation of the ditch sorption capacity.

\section{Conclusion}

In this paper, we present an a priori estimation of the variation of ditch pesticide sorption capacities and an analysis of the factors that control pesticide sorption for a set of farmed ditches. We also propose two new indicators for estimating the global ditch bed sorption capacity. These indicators were evaluated on three head-water catchments with non-permanent flow, but are suitable for both temporary and permanent flow conditions.

Ditch beds are composed of soil, living and decaying vegetation and ash in variable proportions according to their pedological substrate and ditch management. Measurements of the adsorption and desorption 


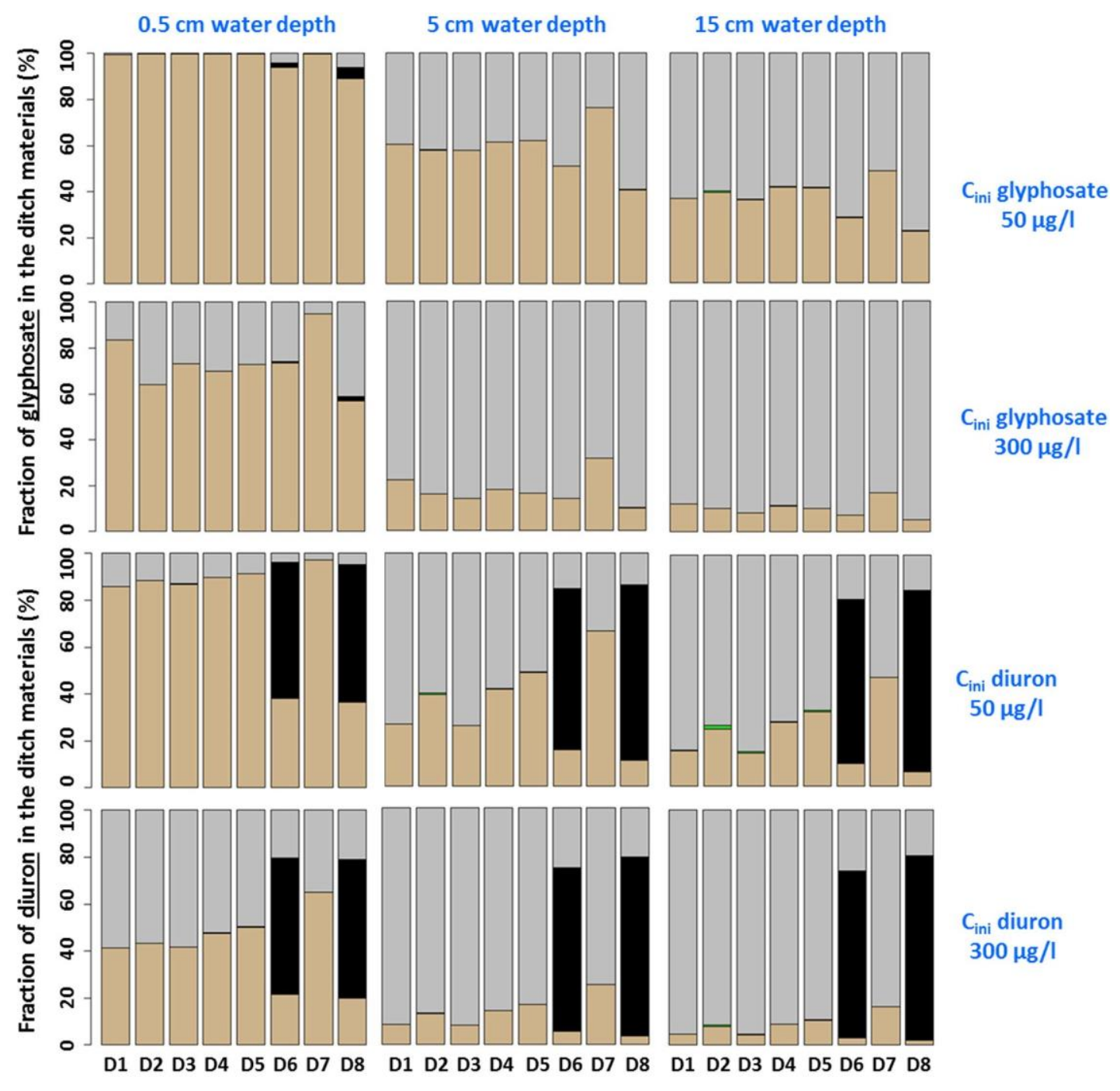

\section{$M_{\text {pest.-soil }} \square M_{\text {pest.-DV }} \square M_{\text {pest.-plants }} \square M_{\text {pest.-ash }} \square M_{\text {pest.-desorbed }}$}

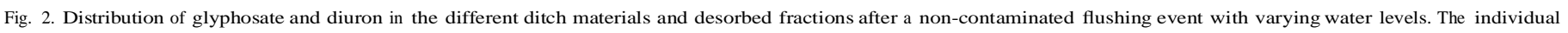

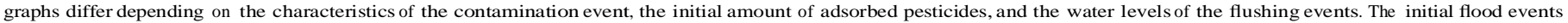

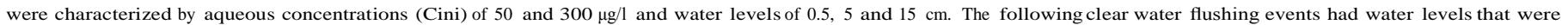
equal to the contaminated events. The results are expressed as the mass percentage of pesticides in a given material to the total amount of adsorbed pesticides.

coefficients of diuron and glyphosate indicate that the sorption affinity of the different ditch-bed materials may also vary largely between pesticides. Diuron exhibited the greatest affinity for ash, dead vegetation and, to a lesser extent, soils, while glyphosate exhibited the greatest affinity for soils and ash. The global sorption capacity of the observed ditches was significant and confirmed that the ditches could have a buffer function by decreasing pesticide pollution in the water. However, the sorption capacity varied largely between ditches (from 1 to 3 or 4 -fold depending on the pesticide studied), which indicates that the buffering potential of ditches is variable. The variation in the sorption capacities between ditches was mainly driven by the nature of soils and abundance of ash. Thus, regularly burning ditch vegetation may improve pesticide retention in the ditch beds. Moreover, mowing provides layers of decayed vegetation, which can be progressively humified in ditch beds increasing the organic carbon content and, consequently, the soil sorption potential for hydrophobic pesticides. Given the range and factors involved in the variation of sorption capacities, they need to be estimated specifically for each ditch according to its specific characteristic and to the effect of various management strategies.
The development of management strategies for operating farm ditch networks to attenuate diffuse pollution by pesticides requires the use of rapid and cost-effective tools. As shown, the new indicators $\mathrm{Kd}_{\text {ditch }}$ and SPRI presented in this study are calculated from simple observations of farm ditch properties and make it possible to rank ditches according to their global sorption potential. Although the used indicators are associated with uncertainties, they may be useful from an operational point of view for investigating the a priori impacts of using different management strategies in ditch networks and can be used when designing optimal strategies for protecting water quality in catchments dominated by cropland.

\section{Acknowledgements}

This work was performed in the framework of a research and development project that was funded by the French Office for Water and Aquatic Bodies (ONEMA 22-6-20). We would like to thank François Garnier for his help with soil sampling in the Morcille and Ruiné catchments and Veronique Gouy and Françoise Vernier for facilitating 


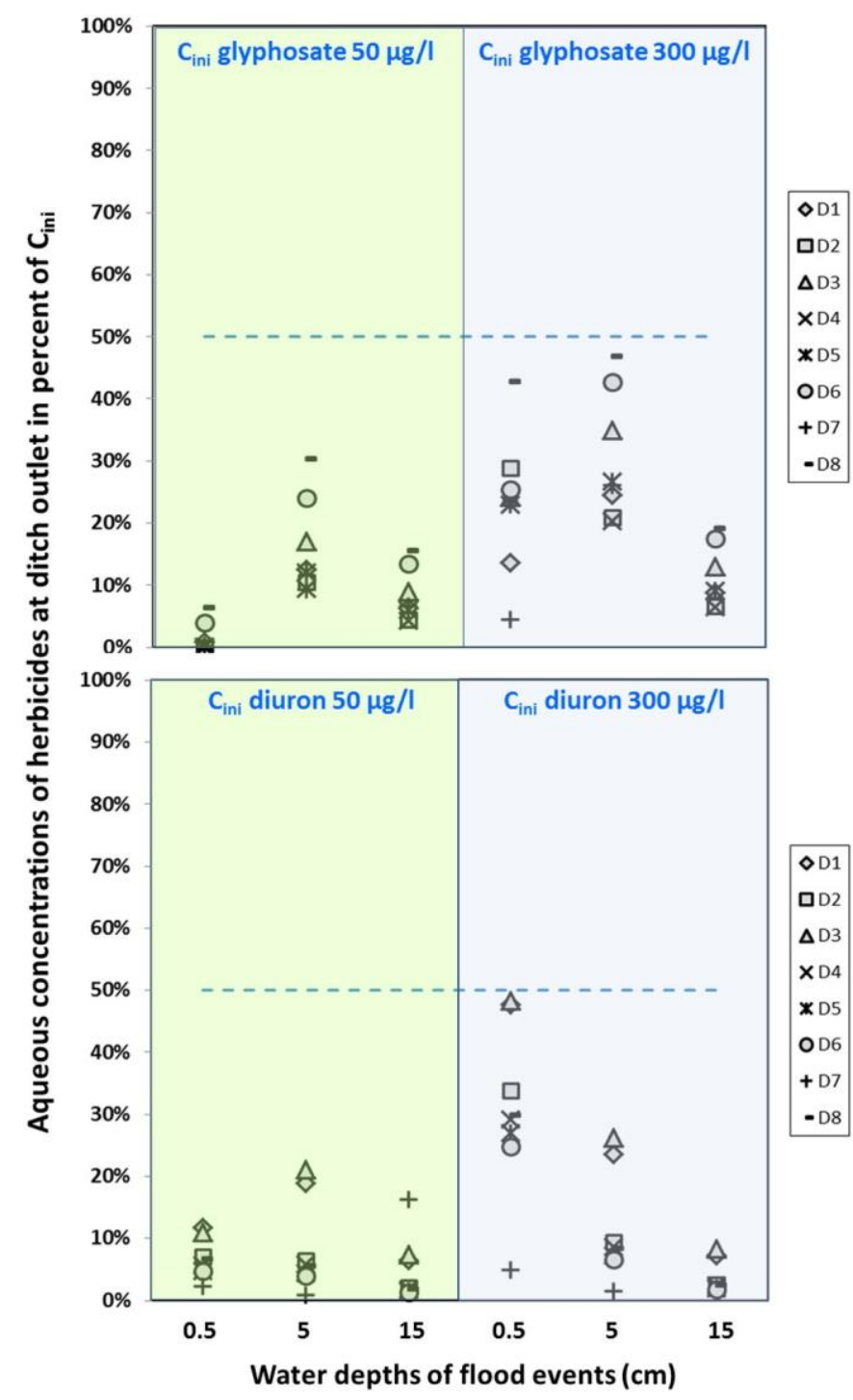

Fig. 3. Estimated glyphosate and diuron concentrations at the ditch outlets during a clear water flushing event.

catchment investigations. The first author is grateful to the French National Institute for Agricultural Research (INRA) for providing her

$\mathrm{Ph}$.D. grant.

Appendix A

Calculations of $\mathrm{Kd}_{\mathrm{ditch}}$ and SPRI are based on the following assumptions: i) adsorption isotherms are linear, ii) pesticide concentrations are uniform throughout the water column and in equilibrium with the

sorbed pesticide contents of all of the ditch-bed materials and iii) the volume of water flowing in the ditch during a flood event is in joint contact with all of the material surfaces. Thereby, the estimated concentrations of the pesticides at the ditch outlet $\left(\mathrm{C}_{\text {out }}\right)$ correspond with the concentration in the water column $\left(\mathrm{C}_{\mathrm{w}}\right)$ when the sorption equilibrium is reached with all of the materials in the ditch bed. In the ditches with limited infiltration potentials, the inflow volume $(\mathrm{V})$ corresponds with the sum of the outflow $\left(\mathrm{V}_{\text {out }}\right)$ and water column $\left(\mathrm{V}_{1}\right)$ volumes for an initially dry ditch

$\mathrm{V}^{1 / 4} \mathrm{~V}_{\text {out }} \mathrm{p} \mathrm{V}_{1}$ mass balance equation when the solid and liquid phases are at equilibrium is

$P_{\text {in }} 1 / 4 P_{\text {out }} \mathbf{p} P_{1} \mathbf{p} \sum_{\mathrm{i}^{1} / 41}^{n} P_{i}$

and

$\mathrm{P}_{\text {in }} 1 / 4 \mathrm{C}_{\text {ini }} \mathrm{V}$

дА $3 \mathrm{P}$

$P_{\text {out }} 1 / 4 C_{\text {out }} V_{\text {out }} 1 / 4 C_{w} V_{\text {out }}$

$P_{1} 1 / 4 C_{w} V_{1}$

$\forall \mathrm{i} \in 1 ; \ldots ; \mathrm{n} ; \mathrm{P}_{\mathrm{i}}{ }^{1 / 4} \mathrm{C}_{\mathrm{w}} \mathrm{M}_{\mathrm{i}} \mathrm{Kd}_{\mathrm{i}}$

where $\mathrm{i}$ refers to one of the $\mathrm{n}$ solid compartments, $\mathrm{M}_{\mathrm{i}}$ the mass of the solid compartment $\mathrm{i}(\mathrm{g}), \mathrm{Kd}_{\mathrm{i}}$ is the sorption coefficient of compartment $\mathrm{i}\left(\mathrm{cm}^{3} / \mathrm{g}\right), \mathrm{P}_{\mathrm{i}}$ is the amount of pesticides sorbed on compartment $\mathrm{i}(\mathrm{g}), \mathrm{P}_{1}$ is the amount of pesticides in the aqueous phase at equilibrium $(\mathrm{g}), \mathrm{P}_{\text {in }}$ is the amount of pesticide entering the ditch $(\mathrm{g}), \mathrm{P}_{\text {out }}$ is the amount of pesticide recovered at the ditch outlet $(\mathrm{g}), \mathrm{C}_{\mathrm{w}}$ is the average pesticide concentration at sorption equilibrium in the ditch and outflow water $\left(\mathrm{g} / \mathrm{cm}^{3}\right), \mathrm{C}_{\text {out }}$ is the pesticide concentration at the ditch outlet $\left(\mathrm{g} / \mathrm{cm}^{3}\right)$ and $\mathrm{C}_{\mathrm{ini}}$ is the aqueous pesticide concentration in the inflow water $\left(\mathrm{g} / \mathrm{cm}^{3}\right)$.

The percentage of pesticide retained on the bed material by sorption during a flood event, which is referred to as the sorption induced pesticide retention indicator (SPRI), is expressed as follows:

SPRI $\quad \frac{i_{1 / 4}^{1 / 4} \sum_{i}^{n} P}{P_{\text {in }}^{n}} 100$

ðА $7 \mathrm{aP}$

By combining Eqs. (A-1) to (A-6), the following equations were obtained:

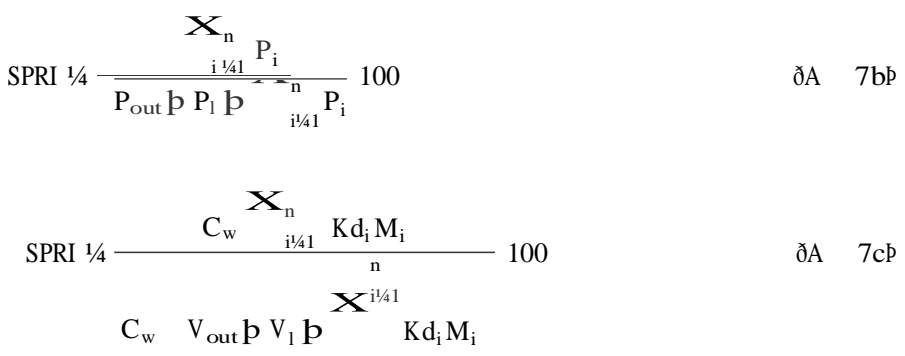

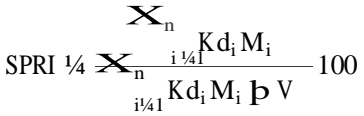

ðА $\quad 7 \mathrm{~d}$

When combining the $\mathrm{Kd}_{\text {ditch }}$ from Eq. (5) with Eq. (A-7d), the SPRI can be expressed as follows:

SPRI $1 / 4 \frac{M K d_{\text {ditch }}}{M K d_{\text {ditch }} \mathbf{p ~ V}} 100$

where $\mathrm{M}=\sum^{\mathrm{n}}$

In the ditches with $\mathrm{n}$ solid compartments (here $\mathrm{n}=4$, namely soils, decaying vegetation, vegetation and ash) with different Kd values, the 
${ }_{i 1 / 41} M_{i}$, which is the total mass of the ditch-bed materials.

Appendix B. Supplementary data

Supplementary data to this article can be found online at http://dx. doi.org/10.1016/j.scitotenv.2016.08.168.

\section{References}

Andrieux, P., Bouzigues, R., Joseph, C., Voltz, M., 1993. Le bassin versant de Roujan: caractéristi ques générales du milieu, Report of the INRA, Montpellier. INRA, Montpellier.

Bailly, J.S., Dages, C., Dollinger, J., Lagacherie, P., Voltz, M., 2015. Protocole de spatialisation et d'évolution d'états de surface de fossés. ONEMA (60 p).

Bundschuh, M., Elsaesser, D., Stang, C., Schulz, R., 2016. Mitigation of fungicide pollution in detention ponds and vegetated ditches within a vine-growing area in Germany. Ecol. Eng. 89, 121-130. http://dx.doi.org/10.1016/j.ecoleng.2015.12.015. 
Crum, S.J.H., van Kammen-Polman, A.M.M., Leistra, M., 1999. Sorption of nine pesticides to three aquatic macrophytes. Arch. Environ. Contam. Toxicol. 37, 310-316. http:// dx.doi.org/10.1007/s002449900519.

Dages, C., Samouëlian, A., Negro, S., Storck, V., Huttel, O., Voltz, M., 2015. Seepage patterns of Diuron in a ditch bed during a sequence of flood events. Sci. Total Environ. 537, 120-128. http://dx.doi.org/10.1016/j.scitotenv.2015.07.130.

Dollinger, J., Dagès, C., Bailly, J.S., Lagacherie, P., Voltz, M., 2015a. Managing ditches for agroecological engineering of landscape. A review. Agron. Sustain. Dev. 35, 999-1020. http://dx.doi.org/10.1007/s13593-015-0301-6.

Dollinger, J., Dagès, C., Voltz, M., 2015b. Glyphosate sorption to soils and sediments pre dicted by pedotransfer functions. Environ. Chem. Lett. 1-15. http://dx.doi.org/10. 1007/s10311-015-0515-5.

Dousset, S., Thévenot, M., Schrack, D., Gouy, V., Carluer, N., 2010. Effect of grass cover on water and pesticide transport through undisturbed soil columns, comparison with field study (Morcille watershed, Beaujolais). Environ. Pollut. Barking Essex 1987 158, 2446-2453. http://dx.doi.org/10.1016/j.envpol.2010.03.028.

FOCUS, 2007. Landscape and Mitigation Factors in Aquatic Risk Assessment. Volume 2 Detailed Technical Reviews. European Commission.

Garon-Boucher, C., 2003. Contribution à l'étude du devenir des produits phytosanitaires lor de l'écoulement dans les fosses: caractérisation physico-chimique et hydrodynamique. Université Joseph Fourier - Grenoble 1 (282p).

Herzon, I., Helenius, J., 2008. Agricultural drainage ditches, their biological importance and functioning. Biol. Conserv. 141, 1171-1183. http://dx.doi.org/10.1016/j.biocon. 2008.03.005.

Levavasseur, F., Biarnès, A., Bailly, J.S., Lagacherie, P., 2014. Time-varying impacts of different management regimes on vegetation cover in agricultural ditches. Agric. Water Manag. 140, 14-19. http://dx.doi.org/10.1016/j.agwat.2014.03.012.

Levavasseur, F., Bailly, J.S., Lagacherie, P., 2016. Are ditch networks optimised for mitigating rill erosion in cultivated Mediterranean landscapes? A numerical experiment Land Use Policy 50, 441-448. http://dx.doi.org/10.1016/j.landusepol.2015.08.033.

Louchart, X., Voltz, M., Andrieux, P., Moussa, R., 2001. Herbicide transport to surface waters at field and watershed scales in a Mediterranean vineyard area. J. Environ. Qual. 30, 982-991.

Margoum, C., Gouy, V., Laillet, B., Dramais, G., 2003. Retention of pesticides by farm ditches. J. Water Sci. 16, 389-405.

Moeys, J., Bergheaud, V., Coquet, Y., 2011. Pedotransfer functions for isoproturon sorption on soils and vadose zone materials. Pest Manag. Sci. 67, 1309-1319. http://dx.doi.org/ $10.1002 / \mathrm{ps} .2187$

Needelman, B.A., Kleinman, P.J.A., Strock, J.S., Allen, A.L., 2007a. Improved management of agricultural drainage ditches for water quality protection: an overview. J. Soil Water Conserv. 62, 171-178

Needelman, B.A., Ruppert, D.E., Vaughan, R.E., 2007b. The role of ditch soil formation and redox biogeochemistry in mitigating nutrient and pollutant losses from agriculture. J. Soil Water Conserv. 62, 207-215.

Passeport, E., Benoit, P., Bergheaud, V., Coquet, Y., Tournebize, J., 2011. Selected pesticides adsorption and desorption in substrates from artificial wetland and forest buffer. En viron. Toxicol. Chem. SETAC 30, 1669-1676. http://dx.doi.org/10.1002/etc.554.
R Core Team, 2014. R: A Language and Environment for Statistical Computing. R Foundation for Statistical Computing, Vienna, Austria URL http://www.R-project.org.

Rabiet, M., Margoum, C., Gouy, V., Carluer, N., Coquery, M., 2010. Assessing pesticide concentrations and fluxes in the stream of a small vineyard catchment - effect of sampling frequency. Environ. Pollut. 158, 737-748. http://dx.doi.org/10.1016/j.envpol. 2009.10.014.

Rogers, M.R., Stringfellow, W.T., 2009. Partitioning of chlorpyrifos to soil and plants in vegetated agricultural drainage ditches. Chemosphere 75, 109-114. http://dx.doi. org/10.1016/j.chemosphere.2008.11.036

Ruppert, D.E., Needelman, B.A., Rabenhorst, M.C., Wester, D.B., 2014. Drainage ditch soil morphology and mineralogy influenced by hydrologic and soil treatments. Soil Horiz. 55 (0). http://dx.doi.org/10.2136/sh 14-01-0003.

SOeS, Ministère de l'écologie, du développement durable et de l'énergie, 2013t. Contamination globale des cours d'eau par les pesticides: Observation et statistiques. URL: http://www.statistiques.developpement-durable.gouv.fr/lessentiel/ar/246/211/ contamination-globale-cours-deau-pesticides.html (accessed 2.8.16).

Stehle, S., Elsaesser, D., Gregoire, C., Imfeld, G., Niehaus, E., Passeport, E., Payraudeau, S., Schäfer, R.B., Tournebize, J., Schulz, R., 2011. Pesticide risk mitigation by vegetated treatment systems: a meta-analysis. J. Environ. Qual. 40, 1068-1080. http://dx.doi. org/10.2134/jeq2010.0510.

Vallée, R., Dousset, S., Billet, D., Benoit, M., 2014. Sorption of selected pesticides on soils, sediment and straw from a constructed agricultural drainage ditch or pond. Environ. Sci. Pollut. Res. 1-11. http://dx.doi.org/10.1007/s11356-013-1840-5.

Vaughan, R.E., Needelman, B.A., Kleinman, P.J.A., Rabenhorst, M.C., 2008. Morphology and characterization of ditch soils at an Atlantic coastal plain farm. Soil Sci. Soc. Am. J. 72, 660. http://dx.doi.org/10.2136/sssaj2006.0102.

Vernier, F., Dubernet, J.F., 1997. The Ruine watershed: evaluation on four years of experiments. Transf. Process Crop Prot. Prod. Model. Catchments Process. Transf. Prod. Phytosanit. Model. Dans bassins les versants 272-276.

Wauchope, R.D., Yeh, S., Linders, J.B.H.J., Kloskowski, R., Tanaka, K., Rubin, B., Katayama, A., Kördel, W., Gerstl, Z., Lane, M., Unsworth, J.B., 2002. Pesticide soil sorption parameters: theory, measurement, uses, limitations and reliability. Pest Manag. Sci. 58, 419-445. http://dx.doi.org/10.1002/ps.489.

Weber, J.B., Wilkerson, G.G., Reinhardt, C.F., 2004. Calculating pesticide sorption coefficients (Kd) using selected soil properties. Chemosphere 55, 157-166. http://dx.doi org/10.1016/j.chemosphere.2003.10.049.

Werner, I., Deanovic, L.A., Miller, J., Denton, D.L., Crane, D., Mekebri, A., Moore, M.T. Wrysinski, J., 2010. Use of vegetated agricultural drainage ditches to decrease toxicity of irrigation runoff from tomato and alfalfa fields in California. USA. Environ. Toxicol. Chem. 29, 2859-2868. http://dx.doi.org/10.1002/etc.356.

Yang, Y., Sheng, G., 2003. Pesticide adsorptivity of aged particulate matter arising from crop residue burns. J. Agric. Food Chem. 51, 5047-5051. http://dx.doi.org/10.1021/ jf0345301. 